Research Article

\title{
Combined association of Presenilin-1 and Apolipoprotein E polymorphisms with maternal meiosis II error in Down syndrome births
}

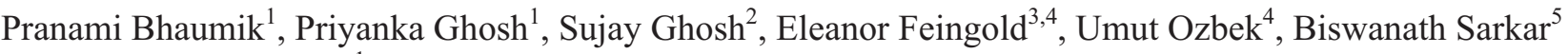 \\ and Subrata Kumar Dey ${ }^{1}$ \\ ${ }^{1}$ Department of Biotechnology, School of Biotechnology and Biological Sciences. Maulana Abul Kalam Azad \\ University of Technology, West Bengal, India \\ ${ }^{2}$ Department of Zoology, University of Calcutta, Ballygunge Science college campus, Kolkata, West Bengal, \\ India \\ ${ }^{3}$ Department of Human Genetics, Graduate School of Public Health, University of Pittsburgh, PA, USA \\ ${ }^{4}$ Department of Biostatistics, Graduate School of Public Health, University of Pittsburgh, Pittsburgh, PA, \\ USA \\ ${ }^{5}$ DNA Laboratory, Anthropological Survey of India, Kolkata, India
}

\begin{abstract}
Alzheimer's disease and Down syndrome often exhibit close association and predictively share common genetic risk-factors. Presenilin-1 (PSEN-1) and Apolipoprotein E (APOE) genes are associated with early and late onset of Alzheimer's disease, respectively. Presenilin -1 is involved in faithful chromosomal segregation. A higher frequency of the $A P O E \& 4$ allele has been reported among young mothers giving birth to Down syndrome children. In this study, 170 Down syndrome patients, grouped according to maternal meiotic stage of nondisjunction and maternal age at conception, and their parents were genotyped for PSEN-1 intron-8 and APOE polymorphisms. The control group consisted of 186 mothers of karyotypically normal children. The frequencies of the PSEN-1T allele and TT genotype, in the presence of the $A P O E \& 4$ allele, were significantly higher among young mothers (<35 years) with meiosis II nondisjunction than in young control mothers $(96.43 \%$ vs. $65.91 \% P=0.0002$ and $92.86 \%$ vs. $45.45 \% P<0.0001$ respectively) but not among mothers with meiosis I nondisjunction. We infer that the co-occurrence of the PSEN-1 T allele and the $A P O E \& 4$ allele associatively increases the risk of meiotic segregation error II among young women.
\end{abstract}

Keywords: Chromosome, genetic polymorphism, karyotype, meiosis, microsatellite markers.

Received: May 19, 2016; Accepted: February 27, 2017.

\section{Introduction}

Alzheimer's disease (AD), a progressive neurodegenerative disorder of old age, and Down syndrome (DS), an intellectual disability due to trisomy of chromosome 21, show co-occurrence. Brain imaging and autopsy studies revealed that Alzheimer's-like neuropathological changes, such as beta amyloid plaques and neurofibrillary tangles were common in DS patients at their forties (Olson and Shaw, 1969; Glenner and Wang, 1984; Mann and Esiri, 1989; Cork, 1990; Yoshimura et al., 1990). The common molecular mechanisms bridging the two disorders include chromosomal missegregation (Potter, 1991; 2008), over-

Send correspondence to Subrata Kumar Dey. Department of Biotechnology, School of Biotechnology and Biological Sciences. Maulana Abul Kalam Azad University of Technology, West Bengal (Formerly known as West Bengal University of Technology), BF _ 142, Salt Lake City, Sector I, Kolkata, West Bengal, India. Pincode: 700064. E- mail: subrata.humangenetics@gmail.com production of amyloid precursor protein (Rumble et al., 1989), oxidative stress and mitochondrial dysfunction (Pagano and Castello, 2012), nuclear factor of activated T cells (NFAT) and tau phosphorylation pathways (Jung et al., 2011; Perluigi et al., 2014), endocytic pathway abnormality (Cataldo et al., 2000), mutation in amyloid precursor protein gene $(A P P)$ (van Leeuwen et al., 1998), presence of Apolipoprotein E epsilon 4 ( $A P O E$ \&4) allele (Del Bo et al., 1997). Familial association of AD and DS has been reported (Yatham et al., 1988; Schupf et al., 2001). Interactions among environmental agents, advancing age (Tanzi and Bertram, 2001; Grant et al., 2002) and a certain genetic polymorphisms (Bertram and Tanzi, 2005) account for $95 \%$ of sporadic late-onset $\mathrm{AD}$, while only $5 \% \mathrm{AD}$ are of early-onset type and due to mutations in APP (Goate et al., 1991), presenilin-1 (PSEN-1) (Sherrington et al., 1995) and presenilin-2 (PSEN-2) (Levy-Lahad et al., 1995; Rogaev et al., 1995) genes on chromosome 21, 14 and 1, respectively. The PSEN-1 gene encodes a protein component of the 
gamma-secretase complex involved in the processing of the amyloid precursor protein (APP) (Karran et al., 1998). Presenilin-1 protein is engaged in many cardinal mechanisms of several molecular pathways (Duff et al., 1996; Alberici et al., 1999; Woo et al., 2009; Ho and Shen, 2011; Trushina et al., 2012), which when impaired lead to the manifestation of AD. This protein also localizes to centromeres, the nuclear envelope of dividing cells, kinetochores at interphase, and is involved in faithful chromosomal segregation (Li et al., 1997). Mutations in PSEN-1 lead to chromosomal instability and trisomy 21 mosaicism in AD patients (Geller and Potter, 1999). Another well-documented molecular marker for both the early-onset (Corder et al., 1993) and sporadic (Brouwers et al., 2008) AD is a polymorphism in the Apolipoprotein E (APOE) gene on chromosome 19. Association of the $A P O E \& 4$ allele with AD has been demonstrated in ethnically different populations (Lehtimaki et al., 1995; Shimada et al., 1997; Tang et al., 1998; Panza et al., 1999; de-Andrade et al., 2000; Kim et al., 2001; Korovaitseva et al., 2001; Chen et al., 2003). On the other hand, DS is the most common aneuploidy in live born humans. The predominant cause of DS is the presence of a supernumerary chromosome 21 , owing to nondisjunction in maternal gametogenesis in the overwhelming majority of cases (Sherman et al., 2007; Allen et al., 2009; Ghosh et al., 2010). Advanced maternal age (Hassold and Chiu, 1985; Allen et al., 2009) and an altered pattern of recombination (Warren et al., 1987; Sherman et al., 1991; Oliver et al., 2008) have been identified as two major risk factors for maternal meiotic errors. Avramopoulos et al. (1996) found a higher of the $A P O E \varepsilon 4$ allele in young mothers having DS children due to chromosomal nondisjunction in the second meiotic division (meiosis II or MII) of oocytes. The association of PSEN-1 intron 8 polymorphism and late-onset AD in North American European descendants was first reported by Wragg et al. (1996) and later supported in many studies (Higuchi et al., 1996; Isoe et al., 1996; Kehoe et al., 1996; Brookes et al., 1997; Ezquerra et al., 1997; Nishiwaki et al., 1997; Tilley et al., 1999); arguments against this association were also produced (PérezTur et al., 1996; Scott et al., 1996; Cai et al., 1997; Lendon et al., 1997; Singleton et al., 1997; Sorbi et al., 1997; Tysoe et al., 1997; Jiang et al., 1999; Bagli et al., 1999; Rodriguez et al., 2000; Chandak et al., 2002; Rassas et al., 2013). The study of a DS sample from Denmark revealed the association of the T allele of the PSEN-1 intronic polymorphism (rs165932) with maternal MII nondisjunction, and thus pointed to a putative role of this polymorphic allele in chromosomal segregation (Petersen et al., 2000). The aim of the present study was to investigate the possibility of a collaborative effect of $P S E N-1$ and $A P O E$ polymorphisms on DS birth in the Indian subcontinent.

\section{Subjects and Methods}

\section{Subjects}

This study included 178 unrelated Bengali individuals with free trisomy 21 and their parents. We recruited 186 women that gave birth to karyotypically normal children as the control group. All subjects were randomly referred from different Medical Colleges and Hospitals of Kolkata and neighbouring areas. The study was approved by the ethical committee of the Maulana Abul Kalam Azad University of Technology. Peripheral blood was collected from the DS children and their parents, as well as from control mothers and their children after taking informed consent.

\section{Cytogenetic analysis}

Classical karyotyping was performed to select only free trisomy 21 DS cases. At least 30 metaphases were analysed from each DS sample to exclude mosaicism.

\section{Determination of parental origin of extra chromosome 21}

Genomic DNA was isolated from blood using a QIAamp DNA Blood Midi Kit (Qiagen). Ten highly polymorphic STR markers, mapped from the pericentromeric region to the telomeric region of the long arm of chromosome 21 were selected to determine the maternal or paternal origin of the extra chromosome 21: D21S1432 - D21S11 D21S1437 - D21S1270 -D21S167 - D21S1412 D21S2055 - D21S1260 - D21S1411 - D21S1446. For determining the stage of meiotic nondisjunction, i.e. MI or MII errors, four additional pericentromeric markers were genotyped: D21S369, D21S215, D21S258 and D21S120. The maternal MI error was inferred, when maternal heterozygosity for these markers was retained in the DS child. If maternal heterozygosity was reduced to homozygosity in the DS child, maternal MII error was considered.

\section{Detection of $A P O E$ and $P S E N-1$ polymorphisms}

Polymorphisms in APOE gene ( $r s 429358$ and rs7412) and $P S E N-1$ intron 8 (rs165932) were investigated by Restriction Fragment Length Polymorphism (RFLP), and direct DNA sequencing in an ABI PRISM 3700 DNA Analyzer platform (Applied Biosystems), after PCR amplification, using oligonucleotide primers previously described by Hixson and Vernier (1990) and Sherrington et al. (1995), respectively. Restriction fragment length polymorphism (RFLP) genotyping of $A P O E$ and PSEN-1 was done, as described by Hixson and Vernier (1990) and Wragg et al. (1996) respectively.

\section{Statistical analysis}

Maternal age was considered as predictor variable in all statistical analyses. For age analyses, both case and control mothers were stratified into young $(<35$ years $)$ and old 
( $>35$ years) groups. Chi-squared tests were performed to compare genotypic and allelic frequencies between case and control mothers, as well as between MI and MII nondisjunction groups, as distinct molecular mechanisms are supposed to be responsible for these errors.

Considered the high number of statistical tests used to compare the many partitions and combinations we created from our original groups of control and DS mothers, the alpha critical level obtained by a simple Bonferroni correction was set at 0.0005 . Since the partitions and rearrangements of the total samples of control and DS mothers were somewhat correlated, we reset this value at the less stringent level alpha $=0.001$.

\section{Results}

STR genotyping revealed that out of the 178 DS trisomies only eight had a paternal meiotic origin, and 170 were the result of maternal nondisjunction. MI nondisjunction was demonstrated in 106 cases ( 53 young mothers and 53 old mothers), and MII nondisjunction in 64 cases (33 young mothers and 31 old mothers). According to the presence of the $A P O E \varepsilon 4$ allele, stage of nondisjunction and age at conception, the 170 case- mothers were stratified into eight groups : (a) $\varepsilon 4$ positive, - MI, - Young, $\mathrm{n}=16$; (b) $\varepsilon 4$ positive, - MI, - Old, $\mathrm{n}=13$; (c) $\varepsilon 4$ positive, - MII, - Young, $\mathrm{n}=14$; (d) $\varepsilon 4$ positive, - MII, - Old, $\mathrm{n}=8$; (e) $\varepsilon 4$ negative, MI, - Young, $\mathrm{n}=37$; (f) $\varepsilon 4$ negative, - MI, - Old, $\mathrm{n}=40 ;(\mathrm{g})$ $\varepsilon 4$ negative, - MII, - Young, $\mathrm{n}=19$; (h) $\varepsilon 4$ negative, - MII, Old, $\mathrm{n}=23$. The control mothers of karyotypically normal children were also categorised as: (a) $\varepsilon 4$ positive, - Young, $\mathrm{n}=22$; (b) $\varepsilon 4$ positive, - Old, $\mathrm{n}=20$; (c) $\varepsilon 4$ negative, Young, $\mathrm{n}=71$; (d) $\varepsilon 4$ negative, - Old, $\mathrm{n}=73$. The distribution of PSEN-1 alleles and genotypes in each group of case and control mothers are presented in Supplementary Tables $\mathrm{S} 1$ and S2, respectively. All groups were in HardyWeinberg equilibrium.

\section{PSEN-1 polymorphism and maternal age}

Stratified analyses for meiotic outcome groups revealed that the TT genotype was significantly more frequent in the group of young mothers with MII nondisjunction compared to young control mothers. $(P=$ 0.0007; Table 1).

\section{$A P O E \& 4$ allele and nondisjunction}

The detailed genotypes and alleles of $A P O E$ gene polymorphism in DS mothers and controls, according to age and meiotic nondisjunction stage are given in the Supplementary Table S3.

In young case mothers, the presence of $\varepsilon 4 /$ - genotypes (i.e. $\varepsilon 4 / \varepsilon 4, \varepsilon 3 / \varepsilon 4$ or $\varepsilon 2 / \varepsilon 4$ ) increased the risk for DS 1.73 times (Table 2). Both the allelic ( $\varepsilon 4)$ and genotypic $(\varepsilon 4 / \varepsilon 4+$ $\varepsilon 3 / \varepsilon 4+\varepsilon 2 / \varepsilon 4)$ frequencies were significantly increased in the MII nondisjunction young group when compared with young controls and with MI nondisjunction old group $(P<$ 0.001 , for genotypic and allelic frequencies). In the group of MII nondisjunction young mothers, the risk of nondisjunction was increased 2.48 times in the presence of the $\varepsilon 4$ allele when compared with the group of MI nondisjunction old mothers $(\mathrm{OR}=2.48,95 \% \mathrm{CI}=1.11$ 5.53; Table 2) and 2.23 times when compared with young control mothers $(\mathrm{OR}=2.23,95 \% \mathrm{CI}=1.12-4.47$; Table 2).

\section{Combined effect of the PSEN-1 T allele and the $A P O E \& 4$ allele and maternal aging on non disjunction}

We found a significant increase in both TT genotypic and $\mathrm{T}$ allelic frequencies in $A P O E \& 4$ positive, - MII nondisjunction,- young case mothers upon comparison with $A P O E \& 4$ positive, - young control mothers $(P<0.00001$ and 0.0002 , respectively; Table 1 ).

These results suggest that the PSEN-1 T allele and the $A P O E \& 4$ allele may collaboratively increase the risk of MII nondisjunction among young mothers.

\section{Discussion}

The aim of the present work was to explore the notion that the etiology of DS birth and AD is somehow related at the molecular level. The result of our analyses suggested that polymorphisms of PSEN-1 might explain the cooccurrence of DS and AD in one same family.

The result of our case control study showed that the 'T allele' of PSEN-1 intronic polymorphism (rs165932) was associated with MII nondisjunction, but not with MI nondisjunction. It is not clear at this point how this polymorphism impacts the chromosome segregation, but two hypotheses have been put forward to explain its molecular role. According to the first hypothesis, the PSEN-1 intron 8 $\mathrm{T}$ allele may be in linkage disequilibrium with a coding segment in the gene itself or in other gene(s) (Hutton and Hardy, 1997); and the second hypothesis postulates that this polymorphic site may affect the pre-mRNA splicing and give rise to a different isoform of the protein, which may affect chromosome segregation (Meshorer and Soreq, 2002). Abnormality in cell cycle regulation is apparent in both familial and sporadic AD cases (Potter, 1991, 2005, 2008; Arendt et al., 1996; Geller and Potter, 1999; Yang et al., 2001, 2006; Nagy, 2005; Yang and Herrup, 2007; Varvel et al., 2008).

The significant increase in T allelic and TT genotypic frequencies in $\varepsilon 4$ positive young mothers with MII nondisjunction would imply a collaborative effect of both alleles in increasing the risk of MII nondisjunction at young age. Avramopoulos et al. (1996) found higher APOE \&4 allele frequencies in young mothers giving birth to DS child due to meiotic II nondisjunction error. This would be ex- 
Table 1 - Comparison of PSEN-1 TT Genotypic and T allelic frequencies among different groups of mothers of DS children and control mothers of karyotypically normal children.

\begin{tabular}{|c|c|c|c|c|c|c|}
\hline \multirow[t]{2}{*}{ Comparisons } & \multicolumn{2}{|c|}{ TT genotypic frequency } & \multirow{2}{*}{$\begin{array}{l}P \text { value of Chi } \\
\text {-squared test }\end{array}$} & \multicolumn{2}{|c|}{$\mathrm{T}$ allelic frequency } & \multirow{2}{*}{$\begin{array}{l}P \text { value of Chi } \\
\text {-squared test }\end{array}$} \\
\hline & Case & Control & & Case & Control & \\
\hline $\begin{array}{l}\text { Case mothers }(\mathrm{N}=170) v s \text {. } \\
\text { Control mothers }(\mathrm{N}=186)\end{array}$ & $55.29 \%$ & $48.92 \%$ & 0.36 & $72.35 \%$ & $68.55 \%$ & 0.65 \\
\hline $\begin{array}{l}\text { MI case mothers }(\mathrm{N}=106) v s \text {. } \\
\text { Control mothers }(\mathrm{N}=186)\end{array}$ & $49.06 \%$ & $48.92 \%$ & 0.98 & $68.39 \%$ & $68.55 \%$ & 0.98 \\
\hline $\begin{array}{l}\text { MII case mothers }(\mathrm{N}=64) \text { vs. } \\
\text { Control mothers }(\mathrm{N}=186)\end{array}$ & $65.63 \%$ & $48.92 \%$ & 0.02 & $78.91 \%$ & $68.55 \%$ & 0.21 \\
\hline $\begin{array}{l}\text { MII case mothers }(\mathrm{N}=64) \text { vs. } \\
\text { MI case mothers }(\mathrm{N}=106)\end{array}$ & $65.63 \%$ & $49.06 \%$ & 0.02 & $78.91 \%$ & $68.39 \%$ & 0.20 \\
\hline $\begin{array}{l}\text { Young case mothers }(\mathrm{N}=86) v s \text {. } \\
\text { Young control mothers }(\mathrm{N}=93)\end{array}$ & $55.81 \%$ & $44.09 \%$ & 0.08 & $73.26 \%$ & $63.98 \%$ & 0.25 \\
\hline $\begin{array}{l}\text { Old case mothers }(\mathrm{N}=84) v s \\
\text { Old control mothers }(\mathrm{N}=93)\end{array}$ & $54.76 \%$ & $53.76 \%$ & 0.89 & $71.43 \%$ & $73.12 \%$ & 0.84 \\
\hline $\begin{array}{l}\text { MI - young case mothers }(\mathrm{N}=53) \text { vs. } \\
\text { Young control mothers }(\mathrm{N}=93)\end{array}$ & $49.06 \%$ & $44.09 \%$ & 0.45 & $68.87 \%$ & $63.98 \%$ & 0.54 \\
\hline $\begin{array}{l}\text { MI - old case mothers }(\mathrm{N}=53) \text { vs. } \\
\text { Old control mothers }(\mathrm{N}=93)\end{array}$ & $49.06 \%$ & $53.76 \%$ & 0.52 & $67.92 \%$ & $73.12 \%$ & 0.54 \\
\hline $\begin{array}{l}\text { MII - young case mothers }(\mathrm{N}=33) \text { vs. Young } \\
\text { control mothers }(\mathrm{N}=93)\end{array}$ & $66.67 \%$ & $44.09 \%$ & 0.0007 & $80.3 \%$ & $63.98 \%$ & 0.04 \\
\hline $\begin{array}{l}\text { MII - old case mothers }(\mathrm{N}=31) \text { vs. } \\
\text { Old control mothers }(\mathrm{N}=93)\end{array}$ & $64.52 \%$ & $53.76 \%$ & 0.14 & $77.42 \%$ & $73.12 \%$ & 0.62 \\
\hline $\begin{array}{l}A P O E \varepsilon 4 \text { positive - young case mothers }(\mathrm{N}=30) v s . \\
A P O E \& 4 \text { positive - young control mothers }(\mathrm{N}=22)\end{array}$ & $66.67 \%$ & $45.45 \%$ & 0.002 & $80 \%$ & $65.91 \%$ & 0.08 \\
\hline $\begin{array}{l}A P O E \varepsilon 4 \text { positive - old case mothers } \\
(\mathrm{N}=21) v s . A P O E \varepsilon 4 \text { positive - old control mothers } \\
(\mathrm{N}=20)\end{array}$ & $52.38 \%$ & $55 \%$ & 0.72 & $69.05 \%$ & $72.5 \%$ & 0.69 \\
\hline $\begin{array}{l}A P O E \& 4 \text { negative - young case mothers }(\mathrm{N}=56) v s . \\
A P O E \& 4 \text { negative - young control mothers }(\mathrm{N}=71)\end{array}$ & $50 \%$ & $43.66 \%$ & 0.34 & $69.64 \%$ & $63.38 \%$ & 0.43 \\
\hline $\begin{array}{l}A P O E \varepsilon 4 \text { negative - old case mothers } \\
(\mathrm{N}=63) v s . A P O E \varepsilon 4 \text { negative - old control mothers } \\
(\mathrm{N}=73)\end{array}$ & $55.56 \%$ & $53.42 \%$ & 0.77 & $72.22 \%$ & $73.29 \%$ & 0.90 \\
\hline $\begin{array}{l}A P O E \varepsilon 4 \text { positive - } \mathrm{MI} \text { - young case mothers }(\mathrm{N}= \\
16) v s . A P O E \varepsilon 4 \text { positive - young control mothers } \\
(\mathrm{N}=22)\end{array}$ & $43.75 \%$ & $45.45 \%$ & 0.80 & $65.62 \%$ & $65.91 \%$ & 0.97 \\
\hline $\begin{array}{l}A P O E \& 4 \text { positive - } \mathrm{MI} \text { - old case mothers }(\mathrm{N}=13) \\
\text { vs. APOE } \varepsilon 4 \text { positive - old control mothers }(\mathrm{N}=20)\end{array}$ & $46.15 \%$ & $55 \%$ & 0.23 & $65.38 \%$ & $72.5 \%$ & 0.40 \\
\hline $\begin{array}{l}A P O E \varepsilon 4 \text { negative }-\mathrm{MI} \text { - young case mothers }(\mathrm{N}= \\
37) v s . A P O E \varepsilon 4 \text { negative - young control mothers } \\
(\mathrm{N}=71)\end{array}$ & $51.35 \%$ & $43.66 \%$ & 0.24 & $70.27 \%$ & $63.38 \%$ & 0.39 \\
\hline $\begin{array}{l}\text { APOE } \varepsilon 4 \text { negative - } \mathrm{MI} \text { - old case mothers }(\mathrm{N}=40) \\
\text { vs. } A P O E \& 4 \text { negative - old control mothers }(\mathrm{N}=73)\end{array}$ & $50 \%$ & $53.42 \%$ & 0.64 & $68.75 \%$ & $73.29 \%$ & 0.59 \\
\hline $\begin{array}{l}A P O E \& 4 \text { positive - MII - young case mothers }(\mathrm{N}= \\
\text { 14) } v s . A P O E \& 4 \text { positive - young control mothers } \\
(\mathrm{N}=22)\end{array}$ & $92.86 \%$ & $45.45 \%$ & $<0.0001$ & $96.43 \%$ & $65.91 \%$ & 0.0002 \\
\hline $\begin{array}{l}A P O E \varepsilon 4 \text { positive - MII - old case mothers }(\mathrm{N}=8) \\
\text { vs. APOE } \varepsilon 4 \text { positive - old control mothers }(\mathrm{N}=20)\end{array}$ & $62.5 \%$ & $55 \%$ & 0.31 & $75 \%$ & $72.5 \%$ & 0.77 \\
\hline $\begin{array}{l}A P O E \& 4 \text { negative - } \mathrm{MII} \text { - young case mothers }(\mathrm{N}= \\
\text { 19) } v S . A P O E \& 4 \text { negative - young control mothers } \\
(\mathrm{N}=71)\end{array}$ & $47.37 \%$ & $43.66 \%$ & 0.57 & $68.42 \%$ & $63.38 \%$ & 0.53 \\
\hline $\begin{array}{l}A P O E \& 4 \text { negative - MII - old case mothers }(\mathrm{N}=23) \\
\text { vs. } A P O E \& 4 \text { negative - old control mothers }(\mathrm{N}=73)\end{array}$ & $65.22 \%$ & $53.42 \%$ & 0.11 & $78.26 \%$ & $73.29 \%$ & 0.56 \\
\hline $\begin{array}{l}A P O E \varepsilon 4 \text { positive - MII case mothers } \\
(\mathrm{N}=22) v s . A P O E \varepsilon 4 \text { positive - MI case mothers }(\mathrm{N} \\
=29)\end{array}$ & $81.82 \%$ & $44.83 \%$ & $<0.0001$ & $88.64 \%$ & $65.52 \%$ & 0.004 \\
\hline
\end{tabular}

Young mothers, $<35$ yrs of age; Old mothers, $<35$ yrs of age

MI, nondisjunction at meiotic division I; MII, nondisjunction at meiotic division II 
Table 2 - Comparative analysis of $A P O E \varepsilon 4 /-$ genotypic and $\varepsilon 4$ allelic frequencies in mothers of DS children and control mothers of karyotypically normal children.

\begin{tabular}{|c|c|c|c|c|c|c|c|c|}
\hline \multirow[t]{2}{*}{ Comparisons } & \multicolumn{4}{|c|}{$\begin{array}{l}\text { APOE } \varepsilon 4 \text { positive genotypic frequency } \\
\qquad(\varepsilon 4 / \varepsilon 4+\varepsilon 3 / \varepsilon 4+\varepsilon 2 / \varepsilon 4)\end{array}$} & \multicolumn{4}{|c|}{ APOE $\varepsilon 4$ allelic frequency } \\
\hline & Chi square & $\begin{array}{l}\text { P value of Chi - } \\
\text { squared test }\end{array}$ & OR & $95 \%$ CI & Chi square & $\begin{array}{l}\text { P value of Chi - } \\
\text { squared test }\end{array}$ & OR & $95 \% \mathrm{CI}$ \\
\hline $\begin{array}{l}\text { Case mothers }(\mathrm{N}=170) \text { vs. control } \\
\text { mothers }(\mathrm{N}=186)\end{array}$ & 2.44 & 0.12 & 1.47 & $0.91-2.36$ & 1.8 & 0.18 & 1.46 & $0.96-2.23$ \\
\hline $\begin{array}{l}\text { Old case mothers }(N=84) \text { vs. Old con- } \\
\text { trol mothers }(N=93)\end{array}$ & 0.57 & 0.45 & 1.22 & $0.60-2.45$ & 0.8 & 0.37 & 1.32 & $0.69-2.50$ \\
\hline $\begin{array}{l}\text { MI - young case mothers }(\mathrm{N}=53) \text { vs. } \\
\text { Young control mothers }(\mathrm{N}=93)\end{array}$ & 1.8 & 0.18 & 1.4 & $0.65-2.97$ & 0.5 & 0.48 & 1.23 & $0.63-2.40$ \\
\hline $\begin{array}{l}\text { MI - old case mothers }(\mathrm{N}=53) \text { vs. Old } \\
\text { control mothers }(\mathrm{N}=93)\end{array}$ & 0.43 & 0.51 & 1.19 & $0.53-2.63$ & 0.21 & 0.64 & 1.16 & $0.55-2.44$ \\
\hline $\begin{array}{l}\text { MII - young case mothers }(\mathrm{N}=33) \text { vs. } \\
\text { Young control mothers }(\mathrm{N}=93)\end{array}$ & 14.89 & 0.0001 & 2.38 & $1.03-5.51$ & 11.29 & 0.0008 & 2.23 & $1.12-4.47$ \\
\hline $\begin{array}{l}\text { MII - old case mothers }(\mathrm{N}=31) \text { vs. } \\
\text { Old control mothers }(\mathrm{N}=93)\end{array}$ & 0.86 & 0.35 & 1.27 & $0.49-3.26$ & 2.69 & 0.1 & 1.6 & $0.70-3.63$ \\
\hline $\begin{array}{l}\text { MII - Young case mothers }(N=33) \text { vs. } \\
\text { MI - old case mothers }(N=53)\end{array}$ & 13.06 & 0.0003 & 2.27 & $0.89-5.76$ & 14.85 & 0.0001 & 2.48 & $1.11-5.53$ \\
\hline
\end{tabular}

Young mothers, $<35$ yrs of age; Old mothers, $>35$ yrs of age

MI, nondisjunction at meiotic division I; MII, nondisjunction at meiotic division II

plained by compromised microcirculation due to the high plasma cholesterol deposition in $A P O E \& 4$ allele carriers causing atherosclerosis in microvasculature surrounding ovarian follicles. This would imply reduced blood flow and oxygen supply, and increased anaerobic products such as lactic acid accumulation in the follicular cell and as a consequence the size of the spindle, could become reduced due to high $\mathrm{pH}$ inside the follicle, resulting in nondisjunction (Gaulden, 1992). Another explanation is that isoform-specific binding of ApoE to microtubule-associated protein would affect microtubule stability and function and, thus, hamper meiotic chromosomal segregation (Strittmatter et al., 1993, 1994; Hansen et al., 1998). Support to this prediction has been provided by Nagy et al. (2000), who showed that trisomy 13 and trisomy 21 conceptuses have a higher $A P O E \& 4$ allele frequency.

A recent study has shown that $A P O E$ regulates telomere dynamics, and the females who carry $A P O E \& 4$ allele experience a six-times higher rate of telomere shortening than non-carriers (Jacobs et al., 2013). Greater erosion of telomere length in Alzheimer's patients with $A P O E \& 4$ allele is also evident (Takata et al., 2012). Interestingly, the study of Ghosh et al. (2010) revealed higher degree of telomere loss in mothers of DS patients resulting from MII nondisjunction than in MI nondisjunction cases and controls. But it is difficult at this point to explain how these data fit together.

Taking all the above into account, we may conclude that the T allele and TT genotype of PSEN-1 polymorphism is associated with MII nondisjunction in younger women giving birth to DS children. Petersen et al. (2000) reported similar findings in Denmark. This result is somewhat interesting as we (Ghosh et al., 2009) and others (Oliver et al., 2008) have found that MII nondisjunction is frequent among older mothers, and represents a maternal age dependent phenomenon. The present set of results suggests that MII nondisjunction can be a maternal age independent phenomenon, when mothers carry the APOE \&4 and $P S E N-1 \mathrm{~T}$ alleles. The gradual increase in the association of the three factors - PSEN-1 T allele, APOE \&4 allele and young age with MII nondisjunction but not with MI nondisjunction, suggests that these two errors are mutually exclusive and involve different molecular mechanisms. Considering the findings of previous studies (Oliver et al., 2008; Ghosh et al., 2009) and the present data together, we could infer predictively that APOE \&4 allele and PSEN-1 rs $165932 \mathrm{~T}$ allele create a microenvironment in the younger oocyte, which mimics the subcellular condition of chronologically older ovum and causes MII nondisjunction, a possibility warranting confirmation through elaborate molecular study. Nevertheless, our study provides the first independent confirmation of PSEN-1 as the prospective molecular candidate that relates AD with DS. The association of the $\mathrm{T}$ allele of $P S E N-1$ intronic polymorphism (rs165932) and the APOE \&4 allele would be the collaborative risk factor for both $\mathrm{AD}$ and $\mathrm{DS}$, reciprocally exacerbating the risk of MII nondisjunction. Moreover, for the very first time we have clearly demonstrated that the distribution 
of risk alleles is statistically similar among controls and MI nondisjunction groups. These results being in accordance with those of Peterson et al. (2000) suggest that the molecular risk factor underlying the association of $\mathrm{AD}$ and $\mathrm{DS}$ is independent of ethnicity. Our findings represent a step towards the understanding of the genetic basis of DS birth and $\mathrm{AD}$ occurance within one same family.

\section{Acknowledgments}

We would like to thank the families participated in the study and professionals who helped us in collection of blood samples. We are thankful to the Director, Anthropological Survey of India, Kolkata, for providing laboratory facilities for some experimental work and Mr. Biswaroop Mookherjee, for his kind help regarding data analysis. The project was funded by Indian Council of Medical Research (ICMR) [grant sanction no. 54/10/2012-HUM-BMS, 31.03.2013].

\section{References}

Alberici A, Moratto D, Benussi L, Gasparini L, Ghidoni R, Gatta LB, Finazzi D, Frisoni GB, Trabucchi M, Growdon JH, et al. (1999) Presenilin 1 protein directly interacts with Bcl-2. J Biol Chem 274:30764-30769.

Allen EG, Freeman SB, Druschel C, Hobbs CA, O'Leary LA, Romitti PA, Royle MH, Torfs CP and Sherman SL (2009) Maternal age and risk for trisomy 21 assessed by the origin of chromosome nondisjunction: A report from the Atlanta and National Down Syndrome Projects. Hum Genet 125:41-52.

Arendt T, Rodel L, Gartner U and Holzer M (1996) Expression of the cyclin-dependent kinase inhibitor p16 in Alzheimer's disease. Neuroreports 7:3047-3049.

Avramopoulos D, Mikkelsen M, Vassilopoulos D, Grigoriadou M and Petersen MB (1996) Apolipoprotein E allele distribution in parents of Down's syndrome children. Lancet 347:862865.

Bagli M, Papassotiropoulos A, Schwab SG, Jessen F, Rao ML, Maier W and Heun R (1999) No association between an intronic polymorphism in the presenilin-1 gene and Alzheimer disease in a German population. J Neurol Sci 167:3436.

Bertram L and Tanzi RE (2005) Alzheimer's disease: One disorder, too many genes? Hum Mol Genet 13:R135-R141.

Brookes AJ, Howell WM, Woodburn K, Johnstone EC and Carothers A (1997) Presenilin-I, presenilin-II, and VLDL-R associations in early onset Alzheimer's disease. Lancet 350:336-337.

Brouwers N, Sleegers K and Van Broeckhoven C (2008) Molecular genetics of Alzheimer's disease: An update. Ann Med 18:1-22.

Cai X, Stanton J, Fallin D, Hoyne J, Duara R, Gold M, Sevush S, Scibelli P, Crawford F and Mullan M (1997) No association between the intronic presenilin polymorphism and Alzheimer's disease in clinic and population-based samples. Am J Med Genet 74:202-203.

Cataldo AM, Peterhoff CM, Troncoso JC, Gomez-Isla T, Hyman BT and Nixon RA (2000) Endocytic pathway abnormalities precede amyloid beta deposition in sporadic Alzheimer's disease and Down syndrome: Differential effects of APOE genotype and presenilin mutations. Am J Pathol 157:277286.

Chandak GR, Sridevi MU, Vas CJ, Panikker DM and Singh L (2002) Apolipoprotein E and presenilin-1 allelic variation and Alzheimer's disease in India. Hum Biol 74:683-693.

Chen D, Zhang JW, Zhang ZX, Zhao HL, Li XQ, Wu YN and Qu QM (2003) Apolipoprotein E gene polymorphisms and Alzheimer disease. Yi Chellan Xue Bao 30:1167-1170.

Corder EH, Saunders AM, Strittmatter WJ, Schmechel DE, Gaskell PC, Small GW, Roses AD, Haines JL and PericakVance MA (1993) Gene dose of apolipoprotein E type e4 allele and the risk of Alzheimer's disease in late onset families. Science 261:921-923.

Cork LC (1990) Neuropathology of Down syndrome and Alzheimer disease. Am J Med Genet Suppl 7:282-286.

de-Andrade FM, Larrandaburu M, Callegari-Jacques SM, Gastaldo G and Hutz MH (2000) Association of apolipoprotein E polymorphism with plasma lipids and Alzheimer'sdisease in a Southern Brazilian population. Braz J Med Biol Res 33:529-537.

Del Bo R, Comi GP, Bresolin N, Castelli E, Conti E, Degiuli A, Ausenda CD and Scarlato G (1997) The apolipoprotein E epsilon4 allele causes a faster decline of cognitive performances in Down's syndrome subjects. J Neurol Sci 145:8791.

Duff K, Eckman C, Zehr C, Yu X, Prada CM, Perez-tur J, Hutton M, Buee L, Harigaya Y, Yager D, et al. (1996) Increased amyloid-beta 42 (43) in brains of mice expressing mutant presenilin 1. Nature 383:710-713.

Ezquerra M, Blesa R, Tolosa E, Lopez Pousa S, Aguilar M, Peña J, Van Broeckhoven C, Ballesta F and Oliva R (1997) The genotype $2 / 2$ of the presenilin-1 polymorphism is decreased in Spanish early-onset Alzheimer's disease. Neurosci Lett 227:201-204.

Gaulden ME (1992) Maternal age effect: The enigma of Down syndrome and other trisomic conditions. Mutat Res 296:6988.

Geller LN and Potter H (1999) Chromosome missegregation and trisomy 21 mosaicism in Alzheimer's disease. Neurobiol Dis 6:167-179.

Ghosh S, Feingold E and Dey SK (2009) Etiology of Down syndrome: Evidence for consistent association among altered meiotic recombination, nondisjunction, and maternal age across populations. Am J Med Genet A 149A:1415-1420.

Ghosh S, Bhaumik P, Ghosh P and Dey SK (2010) Chromosome 21 nondisjunction and Down syndrome birth in an Indian cohort: Analysis of incidence and aetiology from family linkage data. Genet Res (Camb) 92:189-197.

Glenner GG and Wang CW (1984) Alzheimer's disease and Down's syndrome: Sharing of a unique cerebrovascular amyloid fibril protein. Biochem Biophys Res Commun 122:1131-1135.

Goate A, Chartier-Harlin MC, Mullan M, Brown J, Crawford F, Fidani L, Giuffra L, Haynes A, Irving N, James L, et al. (1991) Segregation of a missense mutation in the amyloid precursor protein gene with familial Alzheimer's disease. Nature 349:704-706. 
Grant WB, Campbell A, Itzhaki RF and Savory J (2002) The significance of environmental factors in the etiology of Alzheimer's disease. J Alzheimers Dis 4:179-189.

Hansen C, Bugge M, Brandt CA, Hertz JM, Tranebjaerg L, Mikkelsen M and Petersen MB (1998) Apolipoprotein E alleles in mothers of trisomy 18 conceptuses. Clin Genet 53:321322.

Hassold T and Chiu D (1985) Maternal age-specific rates of numerical chromosome abnormalities with special reference to trisomy. Hum Genet 70:11-17.

Higuchi S, Muramatsu T, Matsushita S, Arai H and Sasaki H (1996) Presenilin-1 polymorphism and Alzheimer's disease. Lancet 347:1186.

Hixson JE and Vernier DT (1990) Restriction isotyping of human apolipoprotein $\mathrm{E}$ by gene amplification and cleavage with HhaI. J Lipid Res 31:545-548.

Ho A and Shen J (2011) Presenilins in synaptic function and disease. Trends Mol Med 17:617-624.

Hutton M and Hardy J (1997) The presenilins and Alzheimer's disease. Hum Mol Genet 6:1639-1646.

Isoe K, Urakami K, Ji Y, Adachi Y and Nakashima K (1996) Presenilin polymorphism in patients with Alzheimer's disease, vascular dementiaand alcohol- associated dementia in Japanese population. Acta Neurol Scand 94:326-328.

Jacobs EG, Kroenke C, Lin J, Epel ES, Kenna HA, Blackburn EH and Rasgon NL (2013) Accelerated cell aging in female APOE- $\varepsilon 4$ carriers: Implications for hormone therapy use. PLoS One 8:e54713.

Jiang S, Lin S, Tang G, Feng G, Qian Y, Wang D, Ren D and Gu N (1999) No association between the intronicpresenilin 1 polymorphism and Alzheimer's disease in the Chinese population. Am J Med Genet 88:1-3.

Jung MS, Park JH, Ryu YS, Choi SH, Yoon SH, Kwen MY, Oh JY, Song WJ and Chung SH (2011) Regulation of RCAN1 protein activity by Dyrk1A protein-mediated phosphorylation. J Biol Chem 286:40401-40412.

Karran EH, Allsop D, Christie G, Davis J, Gray C, Mansfield F and Ward RV (1998) Presenilins in search of functionality. Biochem Soc Trans 26:491-496.

Kehoe P, Williams J, Holmans P, Liddell M, Lovestone S, Holmes C, Powell J, Neal J, Wilcock G and Owen MJ (1996) Association between a PS 1 intronic polymorphism and late onset Alzheimer's disease. Neuroreport 7:2155-2158.

Kim HC, Kim DK, Choi IJ, Kang KH, Yi SD, Park J and Park YN (2001) Relation of apolipoprotein E polymorphism to clinically diagnosed Alzheimer's disease in the Korean population. Psychiatry Clin Neurosci 55:115-120.

Korovaitseva GI, Shcherbatykh TV, Selezneva NV, Gavrilova SI, Golimbet VE, Voskresenskaia NI and Rogaev EI (2001) Genetic association between the apolipoprotein $\mathrm{E}(\mathrm{ApoE})$ gene alleles and various forms of Alzheimer's disease. Genetika 37:529-535.

Lehtimäki T, Pirttilä T, Mehta PD, Wisniewski HM, Frey H and Nikkari T (1995) Apolipoprotein E polymorphism and its influence on apoE concentrations in the cerebrospinal fluid in Finnish patients with Alzheimer's disease. Hum Genet 95:39-42.

Lendon CL, Myers A, Cumming A, Goate AM and St Clair D (1997) A polymorphism in the presenilin 1 gene does not modify risk for Alzheimer's disease in a cohort with sporadic early onset. Neurosci Lett 228:212-214.
Levy-Lahad E, Wasco W, Poorkaj P, Romano DM, Oshima J, Pettingell WH, Yu CE, Jondro, PD, Schmidt SD, Wang K, et al. (1995) Candidate gene for the chromosome 1 familial Alzheimer's disease locus. Science 269:973-977.

Li J, Xu M, Zhou H, Ma J and Potter H (1997) Alzheimer presenilins in the nuclear membrane, interphase kinetochores, and centrosomes suggest role in chromosome segregation. Cell 90:917-927.

Mann DM and Esiri MM (1989) The pattern of acquisition of plaques and tangles in the brains of patients under 50 years of age with Down's syndrome. J Neurol Sci 89:169-179.

Meshorer E and Soreq H (2002) Pre-mRNA splicing modulations in senescence. Aging Cell 1:10-16.

Nagy B, Bán Z, Tóth-Pál E, Papp C, Fintor L and Papp Z (2000) Apolipoprotein E allele distribution in trisomy 13, 18, and 21 conceptuses in Hungarian population. Am J Clin Pathol 113:535-538.

Nagy Z (2005) The last neuronal division: A unifying hypothesis for the pathogenesis of Alzheimer's disease. J Cell Mol Med 9:531-541.

Nishiwaki Y, Kamino K, Yoshiiwa A, Sato N, Tateishi K, Takeda M, Kobayashi T, Yamamoto H, Nonomura Y, Yoneda H, et al. (1997) T/G polymorphism at intron 9 of presenilin 1 gene is associated with, but not responsible for sporadic late-onset Alzheimer's disease in Japanese population. Neurosci Lett 227:123-126.

Oliver TR, Feingold E, Yu K, Cheung V, Tinker S, Yadav-Shah M, Masse N and Sherman SL (2008) New insight into human nondisjunction of chromosome 21 in oocyte. PloS Genet 4:e1000033.

Olson MI and Shaw CM (1969) Presenile dementia and Alzheimer's disease in mongolism. Brain 92:147-156.

Pagano G and Castello G (2012) Oxidative stress and mitochondrial dysfunction in Down syndrome. Adv Exp Med Biol 724:291-299.

Panza F, Solfrizzi V, Torres F, Mastroianni F, Del Parigi A, Colacicco AM, Basile AM, Capurso C, Noya R and Capurso A (1999) Decreased frequency of apolipoprotein E epsilon4 allele from Northern to Southern Europe in Alzheimer's disease patients and centenarians. Neurosci Lett 277:53-56.

Pérez-Tur J, Wavrant-De Vrieze F, Lambert JC and ChartierHarlin MC (1996) Presenilin-1 polymorphism and Alzheimer's disease. The Alzheimer's Study Group. Lancet 347:1560-1561.

Perluigi M, Pupo G, Tramutola A, Cini C, Coccia R, Barone E, Head E, Butterfield DA and Di Domenico F (2014) Neuropathological role of PI3K/Akt/mTOR axis in Down syndrome brain. Biochim Biophys Acta 1842:1144-1153.

Petersen MB, Karadima G, Samaritaki M, Avramopoulos D, Vassilopoulos D and Mikkelsen M (2000) Association between presenilin-1 polymorphism and maternal meiosis II errors in Down syndrome. Am J Med Genet 93:366-372.

Potter H (1991) Review and hypothesis: Alzheimer disease and Down syndrome chromosome 21 nondisjunction may underlie both disorders. Am J Hum Genet 48:1192-1200.

Potter H (2005) Cell cycle and chromosome segregation defects in Alzheimer's disease. In: Copani A and Nicoletti F (eds) Cell Cycle Mechanisms and Neuronal Cell Death. Landes Bioscience, Austin, pp 55-78.

Potter H (2008) Down syndrome and Alzheimer's disease: Two sides of the same coin. Fut Neurol 3:29-37. 
Rassas AA, Fredj SH, Khiari HM, Sahnoun S, Bibi A, Siala H, Mrabet A and Messaoud T (2013) No association between an intronic polymorphism in the presenilin-1 gene and Alzheimer disease in a Tunisian population. J Neural Transm 120:1355-1358.

Rodriguez MT, Calella AM, Silva S, Munna E, Modena P, Chiesa R, Terrevazzi S, Ruggieri RM, Palermo R, Piccoli F, et al. (2000) Apolipoprotein E and intronic polymorphism of presenilin 1 and alpha-1-antichymotrypsin in Alzheimer's disease and vascular dementia. Dement Geriatr Cogn Disord 11:239-244.

Rogaev EI, Sherrington R, Rogaeva EA, Levesque G, Ikeda M, Liang Y, Chi H, Lin C, Holman K, Tsuda T, et al. (1995) Familial Alzheimer's disease in kindreds with missense mutations in a gene on chromosome 1 related to the Alzheimer's disease type 3 gene. Nature 376:775-778.

Rumble B, Retallack R, Hilbich C, Simms G, Multhaup G, Martins R, Hockey A, Montgomery P, Beyreuther K and Masters CL (1989) Amyloid A4 protein and its precursor in Down's syndrome and Alzheimer's disease. N Engl J Med 320:1446-1452.

Schupf N, Kapell D, Nightingale B, Lee JH, Mohlenhoff J, Bewley S, Ottman R and Mayeux R (2001) Specificity of the fivefold increase in AD in mothers of adults with Down syndrome. Neurology 57:979-984.

Scott WK, Growdon JH, Roses AD, Haines JL and Pericak-Vance MA (1996) Presenilin-1 polymorphism and Alzheimer's disease. Lancet 347:1186-1187.

Sherman SL, Takaesu N, Freeman SB, Grantham M, Phillips C, Blackstone RD, Jacobs PA, Cockwell AE, Freeman V, Uchida I, et al. (1991) Trisomy 21: Association between reduced recombination and nondisjunction. Am J Hum Genet 49:608-620.

Sherman SL, Allen EG, Bean L and Freeman SB (2007) Epidemiology of Down syndrome. Ment Retard Dev Disab Res Rev 13:221-227.

Sherrington R, Rogaev EI, Liang Y, Rogaeva EA, Levesque G, Ikeda M, Chi H, Lin C, Li G, Holman K, et al. (1995) Cloning of a gene bearing missense mutations in early-onset familial Alzheimer's disease. Nature 375:754-760.

Shimada K, Yasuda M and Maeda K (1997) Apolipoprotein E genotype as a risk factor in Japanese patients with early onset and late onset Alzheimer's disease. Seishin Shinkeigaku Zasshi 99:575-587.

Singleton AB, Lamb H, Leake A, McKeith IG, Perry RH and Morris CM (1997) No association between an intronic polymorphism in the presenilin-1 gene and Alzheimer's disease. Neurosci Lett 234:19-22.

Sorbi S, Nacmias B, Tedde A, Forleo P, Piacentini S, Latorraca S and Amaducci L (1997) Presenilin-1 gene intronic polymorphism in sporadic and familial Alzheimer'sdisease. Neurosci Lett 222:132-134.

Strittmatter WJ, Saunders AM, Schmechel D, Pericak-Vance M, Enghild J, Salvesen GS and Roses AD (1993) Apolipoprotein E: high-avidity binding to beta-amyloid and increased frequency of type 4 allele in late-onset familial Alzheimer disease. Proc Natl Acad Sci U S A 90:1977-1981.

Strittmatter WJ, Saunders AM, Goedert M, Weisgraber KH, Dong LM, Jakes R, Huang DY, Pericak-Vance M, Schmechel D and Roses AD (1994) Isoform specific interaction of apolipoprotein $\mathrm{E}$ with microtubule associated protein tau: Impli- cations for Alzheimer disease. Proc Natl Acad Sci U S A 91:11183-11186.

Takata Y, Kikukawa M, Hanyu H, Koyama S, Shimizu S, Umahara T, Sakurai H, Iwamoto T, Ohyashiki $\mathrm{K}$ and Ohyashiki JH (2012) Association between ApoE phenotypes and telomere erosion in Alzheimer's disease. J Gerontol A Biol Sci Med Sci 67:330-335.

Tang MX, Stern Y, Marder K, Bell K, Gurland B, Lantigua R, Andrews H, Feng L, Tycko B and Mayeux R (1998) The APOE-epsilon4 allele and the risk of Alzheimer disease among African Americans, Whites and Hispanics. JAMA 279:751-755.

Tanzi RE and Bertram L (2001) New frontiers in Alzheimer's disease genetics. Neuron 32:181-184.

Tilley L, Morgan K, Grainger J, Marsters P, Morgan L, Lowe J, Xuereb J, Wischik C, Harrington C and Kalsheker N (1999) Evaluation of polymorphisms in the presenilin-1 gene and the butyrylcholinesterase gene as risk factors in sporadic Alzheimer's disease. Eur J Hum Genet 7 659-663.

Trushina E, Nemutlu E, Zhang S, Christensen T, Camp J, Mesa J, Siddiqui A, Tamura Y, Sesaki H, Wengenack TM, et al. (2012) Defects in mitochondrial dynamics and metabolomic signatures of evolving energetic stress in mouse models of familial Alzheimer's disease. PLoS One 7:e32737.

Tysoe C, Whittaker J, Cairns NJ, Atkinson PF, Harrington CR, Xuereb J, Wilcock G and Rubinsztein DC (1997) Presenilin-1 intron 8 polymorphism is not associated with autopsy-confirmed late-onset Alzheimer's disease. Neurosci Lett 222:68-69.

van Leeuwen FW, de Kleijn DP, van den Hurk HH, Neubauer A, Sonnemans MA, Sluijs JA, Köycü S, Ramdjielal RD, Salehi A, Martens GJ, et al. (1998) Frameshift mutants of beta amyloid precursor protein and ubiquitin-B in Alzheimer's and Down patients. Science 279:242-247.

Varvel NH, Bhaskar K, Patil AR, Pimplikar SW, Herrup K and Lamb BT (2008) Abeta oligomers induce neuronal cell cycle events in Alzheimer's disease. J Neurosci 28:1078610793.

Warren AC, Chakravarti A, Wong C, Slaugenhaupt SA, Halloran SL, Watkins PC, Metaxotou C and Antonarakis SE (1987) Evidence for reduced recombination on the nondisjoined chromosomes 21 in Down syndrome. Science 237:652-654.

Woo HN, Park JS, Gwon AR, Arumugam TV and Jo DG (2009) Alzheimer's disease and Notch signaling. Biochem Biophys Res Commun 390:1093-1097.

Wragg M, Hutton M and Talbot C (1996) Genetic association between intronic polymorphism in presenilin-1 gene and lateonset Alzheimer's disease. Alzheimer's Disease Collaborative Group. Lancet 347:509-512.

Yang Y, Geldmacher DS and Herrup K (2001) DNA replication precedes neuronal cell death in Alzheimer's disease. J Neurosci 21:2661-2668.

Yang Y, Varvel NH, Lamb BT and Herrup K (2006) Ectopic cell cycle events link human Alzheimer's disease and amyloid precursor protein transgenic mouse models. J Neurosci 26:775-784.

Yang Y and Herrup K (2007) Cell division in the CNS: Protective response or lethal event in post-mitotic neurons? Biochim Biophys Acta 1772:457-466. 
Yatham LN, McHale PA and Kinsella A (1988) Down syndrome and its association with Alzheimer's disease. Acta Psychiatr Scand 77:38-41.

Yoshimura N, Kubota S, Fukushima Y, Kudo H, Ishigaki H and Yoshida Y (1990) Down's syndrome in middle age. Topographical distribution and immunoreactivity of brain lesions in an autopsied patient. Acta Pathol Jpn 40:735-743.

\section{Supplementary material}

The following online material is available for this article:
Table S1 - PSEN-1 genotypic and allelic frequencies in mothers of DS children.

Table S2 - PSEN-1 genotypic and allelic frequencies in control mothers.

Table S3 - APOE genotypic and allelic frequencies in mothers of DS children and control mothers.

Associate Editor: Angela M. Vianna-Morgante

License information: This is an open-access article distributed under the terms of the Creative Commons Attribution License (type CC-BY), which permits unrestricted use, distribution and reproduction in any medium, provided the original article is properly cited. 